\title{
Organ Weights and Intestinal Morphology of Broiler Chickens Fed Diets Containing Different Supplements
}

\author{
S.S. Chauhan ${ }^{1,2}$, R.K. Sharma ${ }^{1}$, B. Singh ${ }^{1}$, S.K. Shukla ${ }^{3}$, J. Palod ${ }^{1}$ and M.K. Singh ${ }^{1} 4^{*}$ \\ ${ }^{1}$ Department of Livestock Production Management, G.B.P.U.A \& T, Pantnagar, (Uttarakhand), INDIA \\ ${ }^{2}$ Department of Livestock Production Management, NDUA\& T, Ayodhya, (Uttar Pradesh), INDIA \\ ${ }^{3}$ Department of Veterinary Medicine, G.B.P.U.A E T, Pantnagar, (Uttarakhand), INDIA \\ ${ }^{4}$ Department of Poultry Science, DUVASU, Mathura, (Uttar Pradesh), INDIA
}

"Corresponding author: MK Singh; E-mail:drmksingh_1@rediffmail.com

Received: 10 Mar., 2020

Revised: 26 April, 2020

Accepted: 04 May, 2020

\begin{abstract}
The present study was evaluated the effect of dietary inclusion of various feed supplements and their combination on the performance index, glucose and serum cholesterol for 6 weeks. Day-old broiler chicks $(n=252)$ were randomly assigned to seven treatment groups, each with 3 replicates. The first treatment was designated as control (T0) in which no supplement was added to the feed, while in treatments $\mathrm{T}_{1}$; organic mineral mixture (Organomin forte), $\mathrm{T}_{2}$; organic mineral mixture (Vannamin), $\mathrm{T}_{3}$; probiotics (Microguard), $\mathrm{T}_{4}$; enzyme (Brozyme -XPR) and probiotics, $\mathrm{T}_{5}$; emulsifier (Lipigon) were provided through feed. In the $\mathrm{T}_{6}$ group, 3 percent less energy was given through feed. The weight of vital organs viz. heart, liver, gizzard, and spleen were significantly $(\mathrm{P}<0.05)$ increased by the feed supplements of which were in the normal range. The gut morphology was also favorably altered due to feed supplementations. This indicates that the organic mineral mixtures, probiotics, enzymes and emulsifiers, and their combinations can be used as a growth promoter in broiler diets and can improve gut health. These products show promising effects as alternatives for antibiotics as pressure to eliminate growth-promoting antibiotic use increases.
\end{abstract}

Keywords: Broiler, intestinal morphology, organ weights

Poultry production has garnered significant landmarks in animal production. From a backyard venture five decades ago (Singh et al., 2017), the Indian Poultry industry has evolved as the most vibrant fast-growing and dynamic sub-sector of agriculture with $16.8 \%$ growth in poultry population over the previous census (Livestock Census, 2019), has witnessed one of the fastest global share of about $6.3 \%$ in egg and $3.3 \%$ in meat production over the year 2015-16, India stands 3rd and 5th position, respectively. The industry has not only grown in size but also productivity. With rapidly changing lifestyles, affluent culture, and a conscious need for general wellness, Indian consumers are now opting for a more protein-rich diet (CARI Vision, 2050). The changing trends are a boon for the poultry sector in India. Feed additives or growth promoters have been used to improve growth rate, feed efficiency, and product quality and to reduce the production cost in poultry Craig et al. (2008). Various antibiotics, anthelmintic, anti-coccidial and hepatic-protectants are used for increasing production. They not only increase the cost of production but have adverse effects on long term usage. Due to the prohibition of most of the antimicrobial feed additives in animal feed and their residual effects in animals (Singh et al., 2014), use of different supplements are becoming more popular Chuka (2014). The effects of organic mineral mixtures, probiotics, enzymes and emulsifiers on the intestinal morphology in association with their organs weights of broilers are still unclear.

How to cite this article: Chauhan, S.S., Sharma, R.K., Singh, B. Shukla, S.K. Palod, J. and Singh, M.K. (2020). Organ weights and intestinal morphology of broiler chickens fed diets containing different supplements. J. Anim. Res., 10(3): 427-431.

Source of Support: None; Conflict of Interest: None क) क्ष 
Therefore, the present investigation was undertaken to study organ weights and intestinal morphological values.

\section{MATERIALS AND METHODS}

\section{Experimental birds and dietary treatments}

The present study was undertaken at the Instructional Poultry Farm (IPF), of Govind Ballabh Pant University of Agriculture and Technology, Pantnagar, U.S. Nagar. The place is located between $28^{\circ} 53^{\prime} 23^{\prime \prime}$ to $30^{\circ} 27^{\prime} 50^{\prime \prime} \mathrm{N}$ and $77^{\circ} 34^{\prime} 27^{\prime \prime}$ to $81^{\circ} 02^{\prime} 22^{\prime \prime} \mathrm{E}$ at $243.84 \mathrm{~m} \mathrm{MSL}$ (mean sea level) in the Tarai region of Uttarakhand State (India). The climate is humid subtropical. Winters are very severe and summers are hot and humid. Temperatures may rise to a maximum of $43^{\circ} \mathrm{C}$ in the summer and fall to a minimum of $2^{\circ} \mathrm{C}$ in the winter. Relative humidity ranges from 15 to $95 \%$ (Singh et al., 2015). The study was conducted on 252 day-olds straight run Ven $\mathrm{Cobb}^{400}$ broiler chicks for 6 weeks under standard management conditions. Feed and water were provided ad libitum. The present study evaluated the effect of dietary inclusion of various feed supplements and their combination on the performance index, glucose and serum cholesterol for 6 weeks. Dayold broiler chicks $(n=252)$ were randomly assigned to seven treatment groups, each with 3 replicates. The first treatment was designated as control $\left(\mathrm{T}_{0}\right)$ in which no supplement was added to the feed, while in treatments $\mathrm{T}_{1}$; organic mineral mixture (Organomin forte), $\mathrm{T}_{2}$; organic mineral mixture (Vannamin), $\mathrm{T}_{3}$; probiotics (Microguard), $\mathrm{T}_{4}$; enzyme (Brozyme -XPR) and probiotics, $\mathrm{T}_{5}$; emulsifier (Lipigon) were provided through feed. In the $\mathrm{T}_{6}$ group, 3 percent less energy was given through feed and at the end of the feeding trial on 42nd day, two birds from each replicate were randomly selected and their organ weights were taken.

\section{Intestinal morphology}

After evisceration, the intestine of the birds were carefully separated and the length of the duodenum (from the ventriculus to the pancreo-biliary duct), jejunum (from the pancreo-biliary duct to Meckel's diverticulum), and ileum (from Meckel's diverticulum to the ileocecal junction) were measured using a measuring tape, villus height was measured from the tip of the villus to the bottom of the villus, crypt depth was measured from the villus bottom to the crypt base and villus height and crypt depth ratio was also calculated.

\section{Statistical analysis}

The data were analysed statistically by using SPSS (Armonk, New York, US) and significant mean differences between the treatments were determined at $\mathrm{P}<0.05$ using Duncan's Multiple Range Test as modified by Kramer (1957). A $p$-value of $<0.05$ was considered as statistically significant.

\section{RESULTS AND DISCUSSION}

\section{Organ weights}

The effect of different supplements on organ weights of the broilers has been shown in Table 1. Liver weight was significantly increased in the broilers of feed supplemented groups in comparison to control. Gizzard and heart weights were significantly increased in the broilers of feed supplemented groups in comparison to control except $\mathrm{T}_{6}$. Pancreas weight was significantly increased in the broilers of feed supplemented groups in comparison to control except $T_{2}$ and $T_{6}$. Spleen weight was significantly increased in the broilers of feed supplemented groups in comparison to control except $\mathrm{T}_{1}$ and $\mathrm{T}_{2}$.

The results of the present study are in agreement with Aguihe et al. (2017) and Kaushal et al. (2018) who found significantly $(\mathrm{P}<0.05)$ higher liver and gizzard weights of broilers fed the diet supplemented with enzymes with probiotics. Awad et al. (2009) and Mahmud et al. (2014) noted a significant $(\mathrm{P}<0.05)$ increase in weights of liver, spleen, gizzard, and heart in broilers fed the diet supplemented with probiotics. Swain et al. (2012) observed that weights of liver, heart, spleen were higher in broilers supplemented with probiotics and yeast. Aguilar et al. (2013) found an increase in liver weight of broilers fed the diet supplemented with an exogenous emulsifier. Sagar et al. (2018) reported a significant $(\mathrm{P}<0.05)$ increase in spleen weight of broilers supplemented with zinc. Sharma et al. (2018) found a significant $(\mathrm{P}<0.05)$ increase in liver, spleen, gizzard, heart and pancreas weights of broilers fed the diet supplemented with enzymes. 
Table 1: Effect of feed supplements on organ weights ( $\%$ of live weight) of broilers

\begin{tabular}{llllll}
\hline Treatments & Liver & Gizzard & Heart & Pancreas & Spleen \\
\hline $\mathrm{T}_{0}$ & $2.25^{\mathrm{a}} \pm 0.02$ & $2.10^{\mathrm{a}} \pm 0.03$ & $0.47^{\mathrm{a}} \pm 0.00$ & $0.17^{\mathrm{a}} \pm 0.00$ & $0.12^{\mathrm{a}} \pm 0.00$ \\
$\mathrm{~T}_{1}$ & $2.35^{\mathrm{b}} \pm 0.02$ & $2.26^{\mathrm{b}} \pm 0.01$ & $0.50^{\mathrm{b}} \pm 0.00$ & $0.20^{\mathrm{b}} \pm 0.00$ & $0.13^{\mathrm{a}} \pm 0.00$ \\
$\mathrm{~T}_{2}$ & $2.43^{\mathrm{c}} \pm 0.01$ & $2.30^{\mathrm{b}} \pm 0.00$ & $0.52^{\mathrm{c}} \pm 0.00$ & $0.18^{\mathrm{a}} \pm 0.00$ & $0.13^{\mathrm{a}} \pm 0.00$ \\
$\mathrm{~T}_{3}$ & $2.47^{\mathrm{cd}} \pm 0.01$ & $2.38^{\mathrm{c}} \pm 0.00$ & $0.54^{\mathrm{d}} \pm 0.00$ & $0.20^{\mathrm{b}} \pm 0.00$ & $0.15^{\mathrm{b}} \pm 0.00$ \\
$\mathrm{~T}_{4}$ & $2.51^{\mathrm{d}} \pm 0.01$ & $2.43^{\mathrm{ce}} \pm 0.01$ & $0.55^{\mathrm{de}} \pm 0.00$ & $0.21^{\mathrm{bc}} \pm 0.00$ & $0.16^{\mathrm{bc}} \pm 0.00$ \\
$\mathrm{~T}_{5}$ & $2.55^{\mathrm{de}} \pm 0.00$ & $2.34^{\mathrm{c}} \pm 0.01$ & $0.53^{\mathrm{cd}} \pm 0.00$ & $0.19^{\mathrm{b}} \pm 0.00$ & $0.14^{\mathrm{b}} \pm 0.00$ \\
$\mathrm{~T}_{6}$ & $2.59^{\mathrm{e}} \pm 0.01$ & $2.16^{\mathrm{ad}} \pm 0.00$ & $0.48^{\mathrm{a}} \pm 0.00$ & $0.18^{\mathrm{a}} \pm 0.00$ & $0.14^{\mathrm{b}} \pm 0.00$ \\
\hline
\end{tabular}

Means bearing different superscripts in a column differ significantly $(\mathrm{P}<0.05)$.

Table 2: Effect of feed supplements on intestinal morphology of broilers

\begin{tabular}{|c|c|c|c|c|c|c|c|}
\hline \multirow[b]{3}{*}{ Treatments } & \multicolumn{7}{|c|}{ Intestinal morphological values } \\
\hline & \multicolumn{4}{|c|}{$\mathbf{c m}$} & \multicolumn{2}{|c|}{$\mu \mathrm{m}$} & \multirow{2}{*}{$\begin{array}{l}\text { - } \\
\text { DVH/DCD }\end{array}$} \\
\hline & $\begin{array}{l}\text { Duodenum } \\
\text { length }\end{array}$ & $\begin{array}{l}\text { Jejunum } \\
\text { length }\end{array}$ & $\begin{array}{l}\text { Ileum } \\
\text { length }\end{array}$ & $\begin{array}{l}\text { Small intestinal } \\
\text { length }\end{array}$ & $\begin{array}{l}\text { Duodenum } \\
\text { villous height } \\
\text { (DVH) }\end{array}$ & $\begin{array}{l}\text { Duodenum } \\
\text { crypt depth } \\
\text { (DCD) }\end{array}$ & \\
\hline $\mathrm{T}_{0}$ & $30.77^{a} \pm 0.16$ & $55.89^{a} \pm 0.56$ & $55.19^{\mathrm{a}} \pm 0.18$ & $141.85^{\mathrm{a}} \pm 0.64$ & $1436.84^{\mathrm{a}} \pm 0.64$ & $301.65^{\mathrm{a}} \pm 0.70$ & $4.76^{\mathrm{a}} \pm 0.00$ \\
\hline $\mathrm{T}_{1}$ & $32.43^{\mathrm{b}} \pm 0.21$ & $57.56^{a} \pm 0.46$ & $56.96^{\mathrm{b}} \pm 0.14$ & $146.95^{\mathrm{b}} \pm 0.80$ & $1526.78^{\mathrm{b}} \pm 0.40$ & $274.83^{b} \pm 0.60$ & $5.55^{\mathrm{b}} \pm 0.13$ \\
\hline $\mathrm{T}_{2}$ & $33.40^{\mathrm{c}} \pm 0.34$ & $58.39^{\mathrm{b}} \pm 0.68$ & $57.49^{b} \pm 0.14$ & $149.28^{b} \pm 0.48$ & $1542.74^{\mathrm{bc}} \pm 0.75$ & $287.49^{c} \pm 0.53$ & $5.36^{\mathrm{c}} \pm 0.00$ \\
\hline $\mathrm{T}_{3}$ & $33.25^{\mathrm{b}} \pm 0.05$ & $59.40^{\mathrm{b}} \pm 0.65$ & $57.93^{b} \pm 0.09$ & $150.58^{b} \pm 0.54$ & $1570.82^{\mathrm{c}} \pm 0.61$ & $301.46^{\mathrm{a}} \pm 0.82$ & $5.21^{\mathrm{d}} \pm 0.07$ \\
\hline $\mathrm{T}_{4}$ & $33.40^{\mathrm{c}} \pm 0.02$ & $59.72^{\mathrm{b}} \pm 0.47$ & $58.14^{\mathrm{b}} \pm 0.02$ & $151.26^{\mathrm{c}} \pm 0.71$ & $1579.47^{\mathrm{c}} \pm 0.80$ & $301.61^{\mathrm{a}} \pm 0.74$ & $5.23^{\mathrm{d}} \pm 0.00$ \\
\hline $\mathrm{T}_{5}$ & $32.95^{\mathrm{b}} \pm 0.11$ & $58.6^{\mathrm{b}} \pm 0.63$ & $57.73^{b} \pm 0.00$ & $149.28^{\mathrm{b}} \pm 0.50$ & $1558.72^{\mathrm{c}} \pm 0.75$ & $297.80^{\mathrm{a}} \pm 0.64$ & $5.23^{\mathrm{d}} \pm 0.00$ \\
\hline $\mathrm{T}_{6}$ & $31.50^{\mathrm{a}} \pm 0.23$ & $56.79^{a} \pm 0.65$ & $56.79^{\mathrm{a}} \pm 0.65$ & $145.08^{\mathrm{a}} \pm 0.70$ & $1457.60^{\mathrm{a}} \pm 0.39$ & $247.61^{\mathrm{d}} \pm 0.65$ & $5.88^{\mathrm{e}} \pm 0.09$ \\
\hline
\end{tabular}

Means bearing different superscripts in a column differ significantly $(\mathrm{P}<0.05)$.

In contrast, Shareef and Al-Dabbagh (2009) and Yadav et al. (2018) reported non-significant $(\mathrm{P}>0.05)$ differences in liver, gizzard, heart, spleen and pancreas weights of broilers fed the diet supplemented with probiotics viz., Saccharomyces cerevisiae and Bacillus subtilis respectively. Zakaria et al. (2010) found nonsignificant $(\mathrm{P}>0.05)$ differences in liver and gizzard weight of broilers fed diet supplemented with enzymes. Narasimha (2013) observed non-significant $(\mathrm{P}>0.05)$ differences in liver, gizzard, pancreas, spleen and heart weights of broilers fed the diet supplemented with enzymes and probiotics.

The weight of vital organs viz. heart, pancreas, liver, gizzard, and spleen were significantly $(\mathrm{P}<0.05)$ increased by the feed supplements of which were in the normal range. The effect of higher inclusion levels of feed supplements and their combination of vital organs increase was more pronounced as compared to lower levels in general.

\section{Intestinal morphological values}

The effect of different feed supplements on the intestinal morphology of the broilers has been shown in Table 2 .

Duodenum, ileum and small intestinal length were significantly increased in the broilers of feed supplemented groups in comparison to control except $\mathrm{T}_{6}$. Jejunum length was significantly $(\mathrm{P}<0.05)$ increased in broilers of feed supplemented groups in comparison to control except $\mathrm{T}_{1}$ and $\mathrm{T}_{6}$. The results are in agreement with the finding of Wang et al. (2016) found a significant $(\mathrm{P}<0.05)$ increase in duodenal, jejunal and ileal length of broilers fed the diet supplemented with probiotics. In contrast, Kaushal et al. (2018) found non-significant $(\mathrm{P}>0.05)$ difference in intestinal length of broilers fed the diet supplemented with multi- enzymes.

Duodenum villous height was significantly increased in the broilers of feed supplemented groups in comparison to 
control except $\mathrm{T}_{6}$. Duodenum crypt depth was significantly decreased in broilers of feed supplemented groups in comparison to control except $\mathrm{T}_{3}, \mathrm{~T}_{4}$, and $\mathrm{T}_{5}$. Villous height: crypt depth ratio was significantly increased in the broilers of feed supplemented groups in comparison to control. Gao et al. (2008) noted a significant $(\mathrm{P}<0.05)$ increase in villi height in the duodenum of broilers fed the diet supplemented with probiotics (Saccharomyces cerevisiae). Luo et al. (2009) found a significant $(\mathrm{P}<0.05)$ increase in villus height: crypt depth ratio in broilers fed the diet supplemented with the enzyme (xylanase). Yang et al. (2008) observed a significantly $(\mathrm{P}<0.05)$ decrease in crypts depth of broilers fed the diet supplemented with the enzyme (xylanase). Zhang et al. (2005) found a significant $(\mathrm{P}<0.05)$ increase in villus height: crypt depth ratio in broilers supplemented with yeast. Awad et al. (2009) found a significant $(\mathrm{P}<0.05)$ decrease in crypt depth and increase in villus height: crypt depth ratio of broilers fed the diet supplemented with probiotics (Lactobacillus species). Echeverry et al. (2016) found significantly $(\mathrm{P}<0.05)$ lower crypt depth and higher villi height: crypt depth ratio in broilers fed the diet supplemented with organic trace minerals. Abdel-Latif et al. (2018) found a significant $(\mathrm{P}<0.05)$ increase in the villi height and villus height: crypt depth ratio in broilers while crypt depth was significantly $(\mathrm{P}<0.05)$ decreased in broilers fed the diet supplemented with probiotics. Kaushal et al. (2018) found a significant $(\mathrm{P}<0.05)$ increase in duodenum villus height and villous height: crypt depth ratio and decrease in duodenum crypt depth of broilers fed the diet supplemented with enzymes and probiotics. Pelicano et al. (2005) noted a significant $(\mathrm{P}<0.05)$ increase in villus height in the duodenum, jejunum, and ileum of broilers fed the diet supplemented with probiotics and prebiotics.

Thus it may be inferred that supplements had altered the gut morphology by stimulating rapid cell division and elongation and more intercellular space leading to increased surface area for absorption of nutrients.

\section{CONCLUSION}

The vital organ weights and gut morphology favourably altered due to feed supplements. These supplements alone or in combination can improve gut health by showing promising effects as alternative to antibiotics.

\section{ACKNOWLEDGMENTS}

Authors are thankful to the Director, Experiment Station, G.B. Pant University of Agriculture and Technology, Pantnagar and Dean, College of Veterinary and Animal Sciences, Pantnagar for providing necessary facilities to conduct the research experiment.

\section{REFERENCES}

Abdel-Latif, M.A., El-Hack, M.E.A., Swelum, A.A., Saadeldin, I.M., Elbestawy, A.R., Shewita, R.S., Ba-Awadh, H.A., Alowaimer, A.N. and El-Hamid, H.S.A. 2018. Single and Combined Effects of Clostridium butyricum and Saccharomyces cerevisiae on Growth Indices, Intestinal Health, and Immunity of Broilers. Animals, 8: 184.

Aguihe, P.C., Kehinde, B.S., Abdulmumini, S., Rojas, I.C.O. and Murakami, A.E. 2017. Effect of dietary probiotic supplementation on carcass traits and haematological responses of broiler chickens fed shea butter cake based diets. Acta Sci., Anim. Sci., 39:3

Aguilar, Y.M., Becerra, J.C., Bertot, R.R., Peláez, J.C., Liu, G. and Hurtado, C.B. 2013. Growth performance, carcass traits and lipid profile of broiler chicks fed with an exogenous emulsifier and increasing levels of energy provided by palm oil. J. Food Agri. Environ., 11(1) : 629 - 633.

Awad, W.A., Ghareeb, K., Abdel Raheem, S. and Bohm J. 2009. Effects of dietary inclusion of probiotic and synbiotic on growth performance, organ weights, and intestinal histomorphology of broiler chickens. Poult. Sci., 88: 49-55.

CARI VISION. 2050. Central Avian Research Institute, Izatnagar, Bareilly, India.

Chuka Ezema. 2014. Comparative study of the effects of probiotic and commercial enzyme on growth rate, haematology and serum biochemistry of broiler chicken. Food Proc. Technol., 5: 9 .

Craig, L., Wyatt ,T. and Mike, B. 2008. Mechanism of Action for Supplemental NSP and Phytate Enzymes in Poultry Diet. Proc. Poult. Nutr. Conf.

Echeverry, H., Yitbarek, A., Munyaka, P., Alizadeh, M., Cleaver, A., Jaimes, G.C., Wang, P.K. O. and Lecompte, J. C. R. 2016. Organic trace mineral supplementation enhances local and systemic innate immune responses and modulates oxidative stress in broiler chickens. Poult. Sci., 95(3): 518- 527.

Gao, J., Zhang, H.J., Yu, S.H., Wu, S.G., Yoon, I., Quigley, J. and Gao, Y.P. 2008. Effects of yeast metabolites in broiler diets on performance and immunomodulatory functions. Poult. Sci., 87: 1377-1384. 
Kaushal, S., Sharma, R.K., Singh, D.V., Shukla, S.K., Kumar, S., Palod, J. and Singh, M.K. 2018. Studies on Organ Weights and Intestinal Morphological values in Ven $\mathrm{Cobb}^{400}$ Broilers by Supplementing Enzymes (Enzymex) and Probiotic (Yeamark). J. Anim. Res., 8(6): 1035-1039.

Kramer, C.Y. 1957. Extension of multiple range tests to group correlated adjusted means. Biometrics, 13: 13-17.

Livestock Census, 2019. All India Report Except Delhi. The Department of Animal Husbandry \& Dairying under Ministry of Fisheries, Animal Husbandry \& Dairying, New Delhi.

Luo, D., Yanga, F., Yang, X., Yao, J., Shi, B. and Zhou, Z. 2009. Effects of xylanase on performance, blood parameters, intestinal morphology, microflora and digestive enzyme activities of broilers fed wheat-based diets. Asian-Aust. J. Anim. Sci., 22(9): 1288-1295.

Mahmud, M.A., Shaba, P., Gana, J., Yisa, H.Y., Ndagimba, R., Bello, A. and Madaki, M.M. 2014. Comparative effects of supplementation of three probiotics on growth and haematological profiles of finishing broiler chickens. J. Vet. $A d v ., 4(6)$ : 564-569.

Narasimha, J., Nagalakshmi, D., Viroji Rao, S.T., Venkateswerlu, M. and Ramana Reddy, Y. 2013. Associative effect of non-starch polysaccharide enzymes and probiotics on performance, nutrient utilization and gut health of broilers fed sub-optimal energy diets. Int. J. Engr. Sci., 2(10): 28-31.

Pelicano, E.R.L., Souza, P.A., Souza, H.B.A., Figueiredo, D.F., Boiago, M.M., Carvalho, S.R. and Bordon, V.F. 2005. Intestinal mucosa development in broiler chickens fed natural growth promoters. Brazilian J. Poult. Sci., 7(4): 221- 229.

Sagar, P.D., Mandal, A.B., Akbar, N. and Dinani. O.P. 2018. Effect of Different Levels and Sources of Zinc on Growth Performance and Immunity of Broiler Chicken during summer. Int. J. Curr. Microbiol. App. Sci., 7(5): 459-471.

Shareef, A.M. and Al-Dabbagh, A.S.A. 2009. Effect of probiotic (Saccharomyces cerevisiae) on performance of broiler chicks. Iraqi J. Vet. Sci., 23: 23-29.

Sharma, R., Baghel, R.P.S., Sharma, S., Mishra, R.K., Vandana Yadav, V. and Aditya Agrawal, A. 2018. Effect of varying levels of enzyme supplementation with higher level of paddy replacing maize on the nutrient utilization and carcass traits of broilers. J. Ento. Zoo. Stu., 6(3): 175-179
Singh, M.K., Sharma, R.K. and Singh, S.K. 2017. Neem Supplementation for Profitable Poultry Production: A Review Indian J. Pout. Sci., 52(3): 239-245.

Singh, M.K., Singh, S.K., Sharma, R.K., Singh, B., Kumar, S., Joshi, S.K., Kumar, Sandeep and Sathapathy, S. 2015. Performance and carcass characteristics of guinea fowl fed on dietary Neem (Azadirachta indica) leaf powder as growth promoter. Ira. J. Vet. Res., 16(1): 78-82.

Singh, M.K., Singh, S.K., Sharma, R.K., Singh, Brijesh, Kumar, Shive, Patoo, R.A., Joshi, S.K., Sathapathy S. and Chaudhari, B.K. 2014. Carcass Chracteristics of Guinea fowl supplemented with Neem (Azadirachta indica) leaf powder. Int. J. Bas. Appl. Agric. Res., 12(3):412-415.

Swain, B.K., Naik, P.K., Chakurkar, E.B. and Singh, N.P. 2012. Effect of combined supplementation of probiotic and yeast on growth, carcass characteristics and economics of production in broiler chickens. Anim. Nutri. Feed Technol., 12: 103-110.

Wang, X., Farnell, Y.Z., Peebles, E.D., Kiess, A.S., Wamsley, K.G.S. and Zhai, W. 2016. Effects of prebiotics, probiotics, and their combination on growth performance, small intestine morphology, and resident Lactobacillus of male broilers. Poult. Sci., 95:1332-1340.

Yadav, M., Dubey, M., Yadav, M. and Shankar, K.S. 2018. Effect of supplementation of probiotic (Bacillus subtilis) on growth performance and carcass traits of broiler chickens. Int.J. Curr. Microbiol. App. Sci., 7(8): 4840-4849.

Yang, Y., Iji, P.A., Kocher, A., Mikkelsen, L.L. and Choct, M. 2008. Effects of xylanase on growth and gut development of broiler chickens given a wheat-based diet. Asian-Aust. $J$. Anim. Sci., 11: 1659-1664.

Zakaria, H.A.H., Mohammad, A.R. and Ishmais, M.A.A. 2010. The influence of supplemental multi-enzyme feed additive on the performance, carcass characteristics and meat quality traits of broiler chickens. Int. J. Poult. Sci., 9: 126-133.

Zhang, A.W., Lee, B.D., Lee, S.K., Lee, K.W., An, G.H., Song, K.B. and Lee, C.H. 2005. Effects of yeast (Saccharomyces cerevisiae) cell components on growth performance, meat quality and ileal mucosa development of broiler chicks. Poult. Sci., 84: 1015-1021. 
